\title{
WILLIAM ROWAN AND CANADA'S 5\& WHOOPING CRANE STAMP: THE PROPOSAL AND A SASKATCHEWAN PHOTOGRAPH
}

Spencer G. Sealy

Department of Biological Sciences

University of Manitoba

Winnipeg, MB R3T 2N2

Spencer.Sealy@umanitoba.ca

On April 4, 1955, Canada Post issued a $5 \not \subset$ stamp that featured two Whooping Cranes (Grus americana) in flight (Figure 1). The timing of the issue of this stamp was at a pivotal juncture in the history of this critically endangered species. By 1942, the number of Whooping Cranes had declined to only 15 or 16 individuals, although that number had risen to $21^{1,2}$ when the stamp was issued. The considerable publicity that surrounded the issue of the "Whooper" stamp gave a boost to the campaign to save this rare bird from extinction. The story of the Whooping Crane's struggle back from the brink of extinction and the cooperative effort between wildlife agencies in Canada and the United States to arrest the decline and manage the species' remarkable comeback has been told many times $^{1-5}$, including at least one account published in the philatelic literature. ${ }^{6}$ Less known are the activities of individuals and groups, initially working independently but later together, during the development of the proposal submitted to the Post Office Department in support of a Whooping Crane stamp, and the circumstances that surrounded the photograph on which the stamp's design was based. What emerges are cooperative efforts of members of natural history societies, support from a philatelic society, and photographs taken by museum biologists - under the eventual guidance of an artist/ scientist's strong conservation ethic to lobby for the production of the stamp.

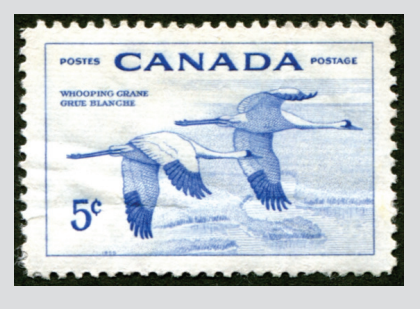

FIGURE 1: $5 \not \subset$ Whooping Crane stamp.

The Whooping Crane is perhaps the best known of Canada's endangered species, and is a flagship species of North American wildlife conservation, symbolizing endangered species worldwide. ${ }^{2}$ Although never common, Whooping Cranes once nested in the parklands of the Prairie Provinces south through North Dakota, Minnesota, and lowa and Illinois. ' The species was last recorded nesting in Saskatchewan in the 1920s. ${ }^{7}$ The individuals that remained were known to winter along the Gulf Coast of Texas, most in the Aransas National Wildlife Refuge', but for decades the whereabouts of the nesting grounds remained obscure. That ended in 1954, when the Canadian Wildlife Service (CWS) initiated aerial surveys of Wood Buffalo National Park, during which biologist William A. Fuller discovered a pair of Whooping Cranes attending a nest in the Sass River area in the Northwest Territories section of the Park. 8,9 Subsequent surveys confirmed the region that straddled the border between northeastern
Alberta and the Northwest Territories as the nesting area for individuals in the wild population. The number of breeding pairs recorded and young produced on the breeding ground in subsequent years could be confirmed after the birds arrived on the wintering ground, thus facilitating tracking of the population over time.

Although Whooping Cranes may live in the wild for more than 20 years, they generally do not produce young until they are at least four years of age, whether in the wild or in captivity. ${ }^{2,3}$ As in most species of crane, Whooping Cranes generally lay two eggs per nesting attempt ${ }^{10,11}$, but usually only one chick, or colt, survives, as was the case of the family group photographed near Viscount, Saskatchewan, in 2017 (Figure 2). One of the eggs may be infertile, or the other chick depredated, killed by its sibling, or succumbed to inclement weather. ${ }^{12}$ This brood reduction puzzled ornithologists, but in the case of the Whooping Crane, it provided a hopeful opportunity to increase the number of young produced each year. By removing one egg from some of the nests (it did not matter which egg), and incubating it artificially, either under a captive female or cross-fostered with a Sandhill Crane (Antigone canadensis), two Whooping Cranes could be produced from a nest instead of one. Back at the original nest, adults incubate the remaining egg and eventually rear the single colt. Ornithologists have shown experimentally that in many species two-egg clutches provide insurance against infertility of one egg or early death of the second young. 13,14 


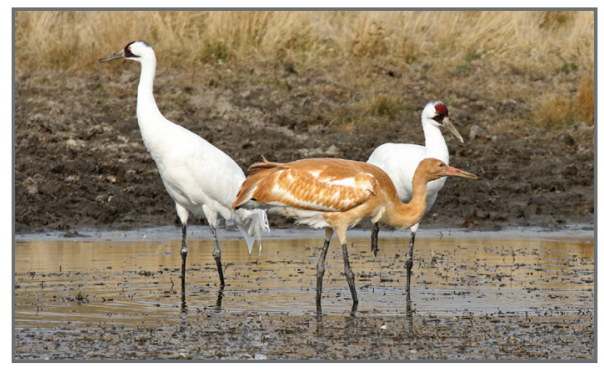

FIGURE 2: A pair of Whooping Cranes accompanied by a single colt, photographed near Viscount, Saskatchewan, October 11, 2017. Photo credit: V. Mann.

\section{The proposal and the designer}

The proposal to issue a Whooping Crane stamp involved a written submission endorsed by the members of natural history societies and backed by an artist's sketch of the desired stamp. The proposal was overseen by the stamp's eventual designer, Dr. William Rowan, F.R.S.C. (Figure 3), a renowned artist and zoologist at the University of Alberta, who signed the first-day-of-issue cover (April 4, 1955) shown in Figure 4. Also issued on that date was a stamp that portrayed the Muskox (Ovibos moschatos), an ungulate that inhabits northern regions. These issues supported Canada's National Wildlife Week.

Although Rowan never saw a Whooping Crane, among the many

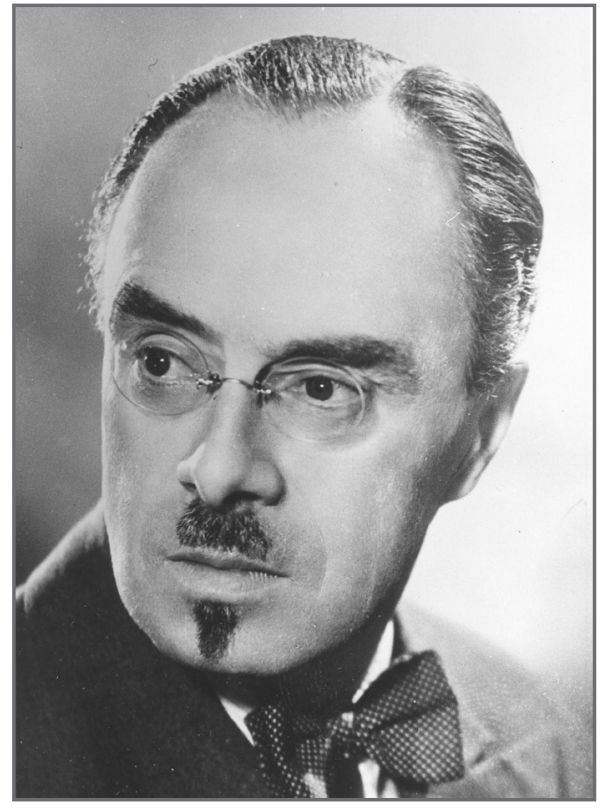

FIGURE 3: Stamp designer, William Rowan. Photograph courtesy of the University of Alberta Archives.

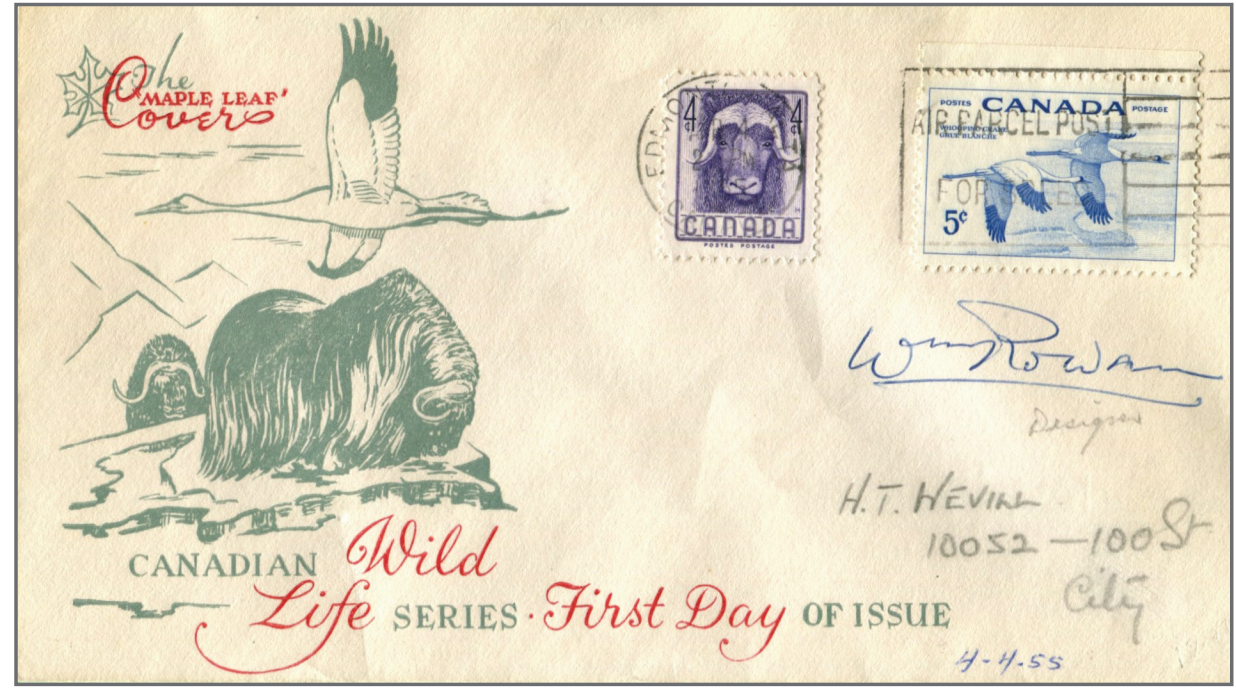

FIGURE 4: Cover post-marked April 4, 1955, the first day of issue of the stamp, commemorating the decline of the Whooping Crane. Mailed at Edmonton and cancelled AIR PARCEL POST FOR SPEED, the envelope is signed by William Rowan, designer of the stamp. (Archived in the Royal Saskatchewan Museum, whose field biologists played important roles in the early recognition of the Whooping Crane's decline and the initial steps in its recovery.)

places he sought birds for study in their natural habitats was the muskeg region north of Edmonton where the possibility that the cranes nested was never far from his mind. Publicity before the stamp was issued incorrectly credited him with the discovery of the Whooping Crane's current nesting ground ${ }^{15}$, but his observations and those of others over the years revealed an urgency to publicize the plight of this majestic species. In the 1920s, with the help of field companions, Rowan spent many summers exploring the muskeg region in search of the breeding ground of a little-known shorebird, the Short-billed Dowitcher (Limnodromus scolopaceus). The dowitcher's nest was eventually discovered and Rowan described a new subspecies ${ }^{16,17}$, but the Whooping Crane eluded him despite investigating first hand numerous reports of nesting in the region that came his way over the years, some considered reliable. ${ }^{18}$ One of Rowan's correspondents was Percy A. Taverner of the National Museum of Canada in Ottawa (now Canadian Museum of Nature), to whom, in a letter dated October 26, 1939, Rowan related a conversation with several local residents who were picking berries in a marsh. They told him how they had encountered a whooper, but without a gun, they "were done out of a first-class feed." 19 The widespread Sandhill Crane, however, nested in the muskeg region and a new subspecies was eventually named in Rowan's honour based on specimens he collected. 17,20

William Rowan combined expertise as a field biologist and laboratory zoologist, and showed that the two approaches can be brought together successfully at a time when field studies were struggling to be accepted, particularly by the President of the $U$ of $A .{ }^{18}$ Armed with many talents and interests - avian physiology and reproduction, migration of birds and fishes, avian taxonomy, variation in birds' eggs, biological cycles, and nature art - Rowan became an early champion for the conservation of wildlife and its habitats. In scientific circles, Rowan was best known for pioneering studies of the influence of increasing periods of day light - photoperiod - on initiation of migration at high latitudes. He conducted experiments in the 1920s in aviaries erected in 
his own backyard in Edmonton. He wondered whether the northward movement of migratory birds in spring was stimulated internally by the gradual increase in the amount of light each day, whereas the southward movement in fall for many species occurred under conditions of ever-decreasing daylight. He also wondered whether seasonal reproductive activities of these birds were similarly influenced. Rowan initially focused on the Dark-eyed Junco (Junco hyemalis)21 for the experiment, but later also studied the American Crow (Corvus brachryhnchos) ${ }^{22}$, both species abundant spring and fall migrants in the Edmonton area.

Rowan hypothesized that if seasonal trends in photoperiod influenced migratory behaviour, subjecting birds artificially to decreasing photoperiod in spring and increases in fall would upset their normal migratory habits. The birds would be predicted to fly in the opposite, that is, the "wrong" direction - south in spring, north in fall. The results were inconclusive. Immediately upon release birds were observed flying south in spring and north in fall, but none of the banded and, hence, identifiable birds were encountered by members of the public late enough following release to support the predicted misdirection of movements. Nevertheless, Rowan became known as the man who made "crows fly backwards." He published his initial findings in 1926, in one of the prestigious journals in his field of the day. ${ }^{21}$ Additional papers followed before he summarized this work in The Riddle of Migration ${ }^{23}$ (Figure 5), published in 1931 and written to appeal to a wider readership.

Taverner directed Rowan to the work on Whooping Crane conservation being conducted in Saskatchewan by personnel at the Saskatchewan Museum of Natural History (hereafter Royal Saskatchewan Museum [RSM]) and by members of the Saskatchewan Natural History Society (SNHS, now Nature Saskatchewan). ${ }^{24}$ Rowan had collected what information he could on this species' status in Alberta, and by 1930 he was supplying information to Fred Bradshaw, chief Game Guardian of Saskatchewan and director of the Museum. ${ }^{18}$ Bradshaw was well placed to coordinate this work and initiated a campaign to increase the public's awareness of the plight of the Whooping Crane, given that the chief migration route passed through Saskatchewan. Where the birds went after travelling north of the settled region was unclear. With the discovery of the wintering ground in Texas, Bradshaw assumed the task of locating the crane's summer home, and its safe keeping in Canada. ${ }^{18}$ Bradshaw was among those who recorded the last known Whooping Crane nests in Saskatchewan, in the early 1920s. ${ }^{5,7}$ It would be another 20 years before the importance of Wood

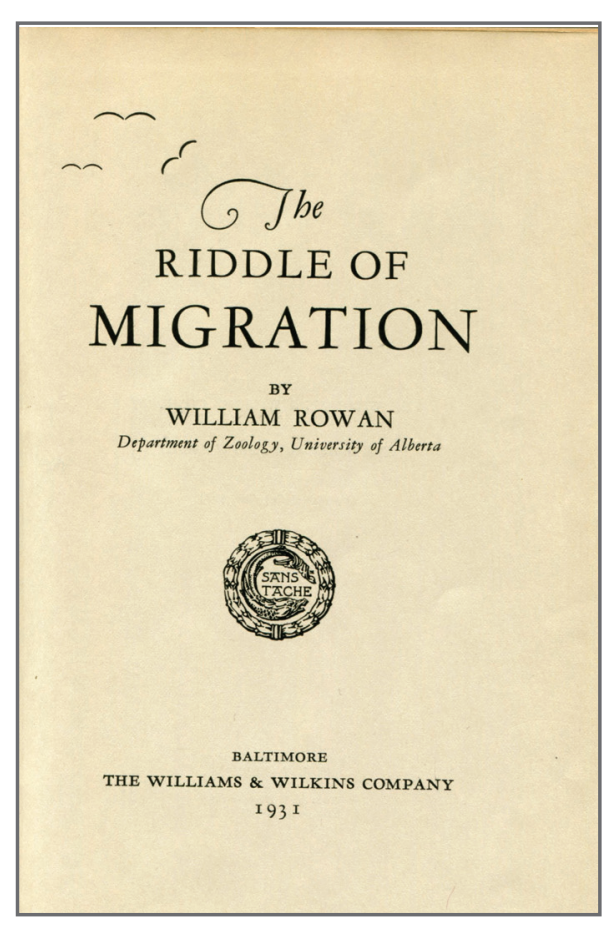

FIGURE 5: Title-page of The Riddle of Migration by William Rowan in which he summarized successes and failures of pioneering experiments on the influence of photoperiod on reproduction and timing of bird migration, conducted in the 1920s.
Buffalo was discovered.

On November 3, 1950, the Post Office Department invited Canadian artists to submit designs for possible use on Canadian stamps. ${ }^{26}$ In response, Rowan submitted sketches of big game animals to the stamp competition, but all were rejected in a form letter on June 28, 1951, that stated "... the Selection Committee did not recommend [his] work for acceptance ... However, the interest you have displayed in this matter and the work done is greatly appreciated." 27 Noticing that the Right Honourable Vincent Massey, whom Rowan had met a few years earlier in London while on leave from his University, had chaired the stamp competition, he wrote to Massey on September 23, 1951, to inquire whether it would be possible to learn why his sketches "didn't suit the judges." 28 There was apparently no response, but Rowan was undaunted. He wrote to Massey again on January 31,1953 , this time exploring the idea of a stamp featuring the rare Whooping Crane: "I would be most grateful if you would give this idea your careful consideration, and if you are in sympathy, to inform me how to proceed. During the past few months I have made this suggestion to numerous people, including two well-known stamp collectors, and they seem agreed that it would be popular as a stamp and both unique and timely as a conservation measure."

Rowan had already envisioned an image of a stamp, showing Whooping Cranes migrating over a bend in the Athabasca River, over which he had recently flown in a light aircraft, and he assumed over which at least some of the few remaining cranes would fly. He offered to send a rough sketch. ${ }^{29}$ Massey must have been encouraging, because Rowan set about to prepare a submission to the Post Office to issue a Whooping 
Crane stamp, but he needed societal support and a photograph on which to base the design. Letters followed to naturalist and philatelic societies in western Canada, soliciting support for a stamp. ${ }^{30}$ Backed by his University, and with considerable input from the Vancouver Natural History Society and the SNHS, Rowan submitted a proposal for a stamp featuring the Whooping Crane. ${ }^{31}$ The photograph he used was taken in Saskatchewan during the Whooping Crane's migration in the fall of 1953.

The level of support for this conservation initiative, and for the stamp, is illustrated by the following announcement to members of the Vancouver Natural History Society, from the honorary secretary, C.B.W. Rogers ${ }^{30}$ :

The Vancouver Natural History Society is sponsoring a plan to assist in solving the mystery of the nesting grounds of the Whooping Crane, and help save it from imminent extinction. We wish an air-mail stamp and cancellation to be made for Canada and the United States, so that by such public notice everyone may be aroused to this danger...

We want every interested individual and organization in Canada to write a letter addressed to myself, .... and to stress the value such a stamp would be in saving this magnificent bird. When all the letters are finally received, they will be bound into a folio, supporting an accompanying letter we will send to the proper authorities in Ottawa, requesting that consideration be given to the issuing of such a stamp ... Once the request is granted, steps will be taken to have the stamp made.

We believe this idea will appeal to you, and that you will wish to help us in the way we have suggested.

\section{The design - Whooping Cranes in flight}

In an early note filed in the
RSM, Fred G. Bard told of an encounter with Whooping Cranes he experienced with his father (Fred Bard, Sr.) and Fred W. Lahrman at the sanctuary at the north end of Last Mountain Lake, Saskatchewan, on September 29, 1949. The population was near its all-time low and the threat of extinction was on their minds:

Sept 29/49 (Dad's birthday) - 3 seen (5:40 pm) feeding on cultivated land in stubble in sanctuary $\mathrm{N}$ end of Last M[ountain] Lake [by] F. Bard Sr, Fred G. Bard, and F. W. Lahrman. They remained only about 3 minutes at 300 yards and then flew south into arms of lake, passed one arm settling on 2nd arm from east side. No calls at all. This sight was impressive. The three majestic creatures rose into the light of the setting sun. All three of us drank in their ra[re] beauty, perhaps these will be the last we'll ever see.

\section{Bard and Lahrman saw Whooping} Cranes again. The photograph of the birds in flight, on which the stamp's design was based, was taken by Fred Lahrman, a field worker, artist and photographer at the RSM who, with then director, Fred G. Bard $^{32,33}$, had extended Bradshaw's efforts to monitor the species' migration through Saskatchewan. The photograph was taken at a body of water near Herbert, Saskatchewan, on the 5th of November, $1953^{24}$, not on the $3 r d$, as stated on a framed copy of the photograph archived in the RSM (Figure 6). The discrepancy in the date apparently arose because both men actually left Regina on November 4 (see field notes below), whereas the birds were not located until the next day, after an overnight stay in Herbert.

The following afternoon, the men returned to the site where the cranes had been sighted the previous day, accompanied by a high school student interested in sketching the

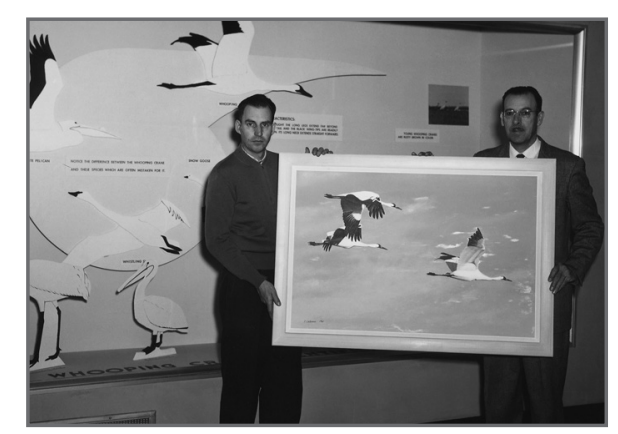

FIGURE 6: Fred W. Lahrman (left) and Fred G. Bard holding the photograph of Whooping Cranes taken by Lahrman near Herbert, Saskatchewan, on November 5, 1953. The photograph formed the basis of the design of the first Whooping Crane stamp issued by Canada Post. Image courtesy of the RSM.

birds. Bard spent the afternoon making plaster molds of the footprints and gathering sedge for the crane case in the museum. Bard's handwritten notes, filed in the RSM and transcribed verbatim below, describe the encounter with the Whooping Cranes, and also reveal challenges faced using cameras of the day.

Nov 4/53 - Mr. Len Chase of Herbert phoned to say birds are the whooping cranes. Fred [Lahrman] and I leave about 2:30 for Herbert, we stop overnight at Hotel. See Fred Lietz who has land on north side of Francis Lake (East 1/s of $5,18,9 A$ ). At 6:30 Fred Lahrman and I drove to north side of lake and stopped at the school which overlooks the lake. This was $7 \mathrm{am}$. The birds were immediately spotted feeding in the stubble. We observed them for a few minutes and circled north and East to approach for pictures when the light was more suitable. We were within 300 yards when they suddenly took flight and lit about $3 / 4$ mile West.

Lahrman walked down to the lake and circled the shore following the draws. I retraced in a circle to approach from the north and west. We met at the washed out road allowance about $1 / 4$ mile east of the feeding cranes. We were planning our approach as we lay in the ditch - when the birds took off again. This time they flew towards us and continued until they came within 100 yards and they turned, 
passing north of us to within 50 yards with perfect light on them. They continued their flight until they were $3 / 4$ of a mile [e]ast. We circled to within 400 yards and then crawled towards them.

Fred Lahrman and I crawled to within 200 yards of them - he then found he had 2 more exposures left. I continued on until I reached the mud flat. Here there was no cover but sparse clumps of rushes. I dodged from one to the other to within 100 yards. The birds stood erect and all three trumpeted loudly, higher at times and different to Sandhill cranes. This beautiful display was performed about 6 times. As I retraced my steps they flew [w]est again.

Rowan was aware of the publicity this photograph had garnered and contacted Bard in late 1953 about possibly using it in the stamp's design. On January 26, 1954, Bard wrote to Rowan, stating "I had given your letter to Mr. Fred Lahrman to acknowledge the request for a Whooping Crane picture. He was handling this and I regret I have left your correspondence until now to answer your inquiry." Bard stated further that "When we photographed the Whooping Cranes at Herbert on November 5th, we wondered whether or not these three would safely make the journey south. At this time, we know they did." 34

Several years later, the RSM highlighted its special role in the conservation of the Whooping Crane, which was centred on Lahrman's famous photograph. The accompanying caption read:

Fred Lahrman, a noted artist who worked at the [RSM], helped to raise awareness about Whoopers by featuring them in museum diorama paintings, and by capturing them on film. One photo of three flying Whooping Cranes taken by Mr. Lahrman was called "the most exceptional photograph of the week" by
Associated Press and was used by most Canadian and U.S. newspapers. This photo won an award of the "Most Outstanding Wildlife Picture of the Year" and was used on a Canadian postage stamp.

Lahrman was involved with Whooping Crane conservation for more than 50 years ${ }^{35}$, and many of his photographs of Whooping Cranes appeared in the pages of Blue Jay, the journal of the SNHS. ${ }^{36}$ Lahrman's work continued with the preparation of a diorama at the RSM that featured a pair of Whooping Cranes at a nest with the typical clutch of two eggs (Figure 7). ${ }^{37}$ According to Museum records uncovered by Glenn Sutter and Marlon Janzen, the diorama may have been based on Valeport marsh at the south end of Last Mountain Lake. The caption on a reference photo noted it was "looking $\mathrm{W}$ and $\mathrm{N}$, before the railroad went through the marsh" — which presumably happened sometime in the 1950s (Sutter, email, March 11, 2019). The exhibit apparently was based on two of the last nests confirmed in Saskatchewan, found by Fred Bradshaw in the KindersleyKerrobert area in 1922. ${ }^{7}$ Sutter presumed that the real nests were used as guides to determine how the display nest was presented, whereas the depicted landscape was based on the Valeport marsh.

\section{The stamp is issued}

Drafts of several sketches of the stamp are archived at the University of Alberta (WR papers, box 48, folder 1088), with one shown in Figure 8 . The stamp was initially proposed as an airmail stamp, with a value of $10 \not c$, but it was eventually issued with a value of $5 \not \subset$. One change in the final version involved correction of the shapes and proportions of black in the cranes' outer primaries, or flight

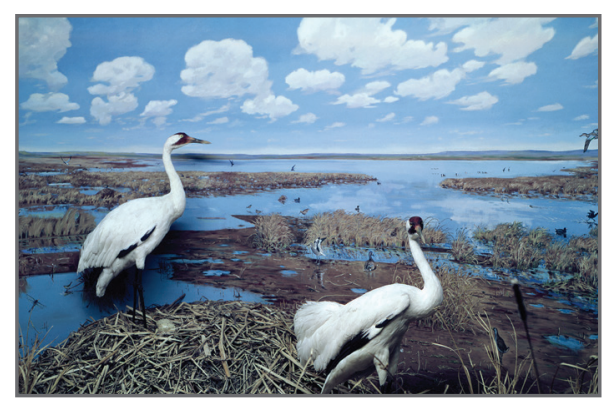

FIGURE 7: Diorama featured in the Royal Saskatchewan Museum that depicted a pair of Whooping Cranes and nest containing the typical clutch of two eggs. Image courtesy of the RSM.

feathers. Rowan indicated that the birds, as depicted in Lahrman's photograph, were sketched against a background of the Athabasca River in northern Alberta. In his words, "This is a sketch design which has taken some note of engraving requirements, but is open to modification. The scene below represents the valley of the Athabasca River as seen from a plane at about 5,000 feet. This is one of the known fly-lines of the whooping crane." 38

Also proposed was a cancel to be used to promote awareness of the Whooping Crane's plight. On March 29, 1955, Rowan wrote to Bard stating, "On Monday next my whooping crane stamp is coming out. I have been in touch with the Post Office at Ottawa to find out what I can about cancelling devices with a suitable slogan and the situation is this. They will only permit one cancelling die in a single city in each of the three prairie provinces and the obvious places seem to be Winnipeg, Regina and Edmonton." 39 Ducks Unlimited and the Edmonton Bird Club covered the cost of the dies used at Winnipeg and Edmonton, respectively; eventually the RSM paid for the cancel used at Regina. Two days after the stamp was issued, Bard congratulated Rowan, stating "... it's a nice tribute to have something like this appear for distribution on our postage stamp to appear during Wildlife Week and to contribute 


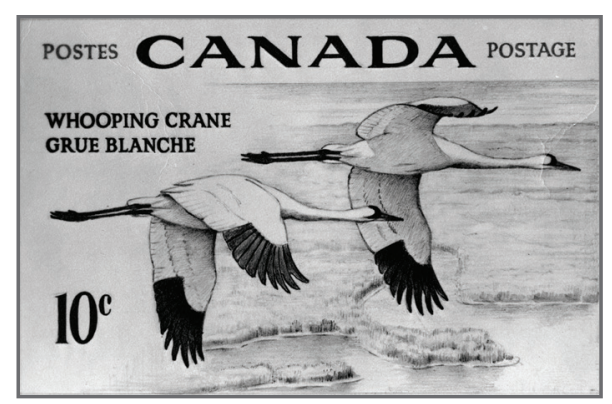

FIGURE 8: Rowan's pencil sketch of the Whooping Crane stamp was reproduced as shown, except for the denomination (University of Alberta Archives Accession UAA 69-16 1084).

coinciding with the migration of these rare birds. I hope we are successful in holding the line and some indication will be that the birds can increase, although it seems too much to hope for." 40

On March 30, 1955, Rowan asked David Adamson of the Post Office Department: "... [to] kindly send a die to each of the Post Masters in Winnipeg, Regina and Edmonton. If you could get them through at your earliest convenience, I would appreciate the effort. The cranes could get north here in a matter of between two and three weeks and I gather from your comments the dies could be manufactured and delivered in about that time." ${ }^{41}$ The preferred, and final wording, as it turned out, was:

"PROTECT WHOOPING CRANES NOW FACING EXTINCTION"

Adamson wrote to Rowan on the day of issue that the "Purchasing and Stationery Division was ordering three special cancelling dies to be distributed to Winnipeg, Regina and Edmonton, with instructions to have the dies placed in operation immediately upon receipt. In order that we may advise the Postmasters concerned, will you please let us know when these dies should be removed from the cancelling machines." ${ }^{41}$ The dies were first used several days after the stamp was issued, to coincide with the average spring-arrival of the migrating cranes on the Canadian Prairies. ${ }^{42} \mathrm{~A}$ cover cancelled at Winnipeg on April 25,
1955 (shown in reference \#6, p. 88), illustrates this use. Whether this slogan cancel was used again in late September and October to coincide with the Whooping Crane's fall migration, as planned, was not confirmed. ${ }^{43,44}$ As expected for a letter mailed outside the three cities, one mailed at Brantford, Ontario, on May 21, 1955 (Figure 9), was machine cancelled, although by that date most or all of the birds would have migrated through Saskatchewan.

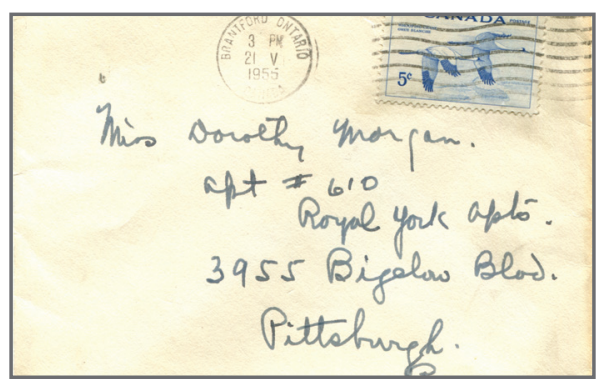

FIGURE 9: Cover bearing the $5 \not \subset$ Whooping Crane stamp postmarked at Brantford, ON, on May 25, 1955.

Rowan's extensive correspondence with natural history societies and Canada Post during the submission of the proposal and selection of the design of the Whooping Crane stamp is archived at the University of Alberta. ${ }^{30}$ The stamp garnered widespread publicity and generated considerable interest among stamp collectors and philatelists, and Rowan was widely praised for his efforts. He received numerous requests for autographed first-day covers, articles were published in philatelic journals, newspapers and magazines, and media requests for interviews were granted in the weeks and months that followed. As hoped, the stamp helped carry the conservation message across the country.

Particularly interested in the stamp was philatelist Lorne Bentham, who wrote to Rowan on February 12,1957 , requesting information that pertained to the conception of the idea for the stamp and the proposal to the postal authorities, samples of the stamp's design, nature of support from philatelic groups, details of Rowan's philatelic interests and affiliations with stamp clubs (there were none), and current Whooping Crane numbers (down to only 24). ${ }^{45}$ In characteristic fashion, Rowan responded in great detail to Bentham's request in a letter of February 21, 1957. ${ }^{45}$ With this information, Bentham published an article in Scott's Monthly Journal and other philatelic journals. ${ }^{46}$

Not everyone was so charitable. No one disputed the worthiness of a stamp promoting the conservation of the majestic and declining Whooping Crane, but lapses of fact emerged in several articles. For example, Rowan was compelled to correct several misstatements in an article entitled "Whooping Crane Model for Stamp", published in the Edmonton Journal on 11 September $1956 .{ }^{47}$ Rowan set the record straight:

I am sorry that Mrs. Barrie doesn't like my whooping crane stamp (to be quite honest, I don't either!) but one can hardly judge the wings of a flying bird from a cabinet example stuffed in a standing pose. The wings of my birds are based on dozens of sketches of and photographs of our large sandhill crane in flight ("sand" crane as it is miscalled in your article) obtained in our local muskegs where it breeds, while the final verdict, just before the finished design went to Ottawa engravers, came from my friend Peter Scott, the world's premier wildfowl artist and doubtless its most competent draughtsman and critic of wings in flight. The wings of all cranes are structurally similar. Mrs. Barrie's crane had no connection whatever with the production of the stamp. ${ }^{48}$

The Whooping Crane to which they referred had been shot by W.H. Barrie at Quill Lake, Saskatchewan, in 1913; the mounted bird was still standing in Mrs. Barrie's living room. Rowan continued, "As for 
other specimens of whooping cranes preserved in Canada, so far from numbering only three as stated in your article, the Royal Ontario Museum alone has a long series of them, while the bird in the Luxton Museum at Banff (not mentioned either in your article) is not even surpassed by Mrs. Barrie's fine specimen." 48 This was not the first time that Rowan, as a scientist, had been called upon to respond to criticism and misrepresentation of the facts.

\section{Beyond Canada}

The Whooping Crane was of international concern, however, and Rowan assumed a Canadian stamp featuring the species would carry an even greater message if the United States also featured this species on a stamp. His inquiries were generally received positively. On December 29, 1953, ornithologist Robert A. McCabe of the University of Wisconsin wrote to Rowan, stating "Your suggestion for using the whooping crane on a Canadian and U.S. stamp sounds like an excellent idea to me. I talked over the general idea with [ornithologist] Bill Schorger and we both think your idea of getting the Audubon Society behind it is the best way to exert pressure, at least here in the U.S." 49 Additional support came from the SNHS, which passed a resolution at the 1954 annual meeting to request the National Audubon Society to approach United States postal authorities to issue a Whooping Crane stamp, "like the proposed five-cent Canadian stamp." 24 On

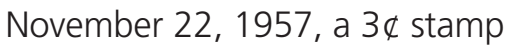
featuring a family group of Whooping Cranes, which included two recently hatched colts (Figure 10), was issued by the United States Post Office. The population of Whooping Cranes in the wild at that time stood at 26 individuals. ${ }^{2}$

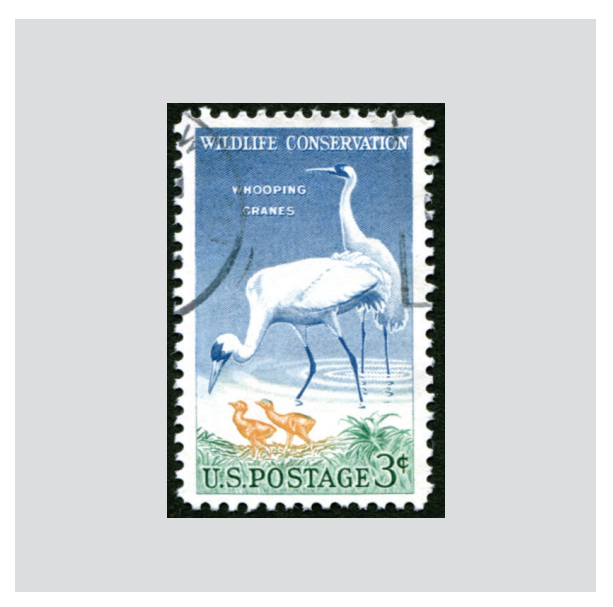

FIGURE 10: Three-cent Whooping Crane stamp issued by the United States Postal Service, November 22, 1957.

Canada Post issued a second stamp featuring a somewhat stylized Whooping Crane on August 20, 2018, which completed the "Birds of Canada" series. The individual depicted was likely in its first or second year, as suggested by the brown feathers of the plumage of the back and on the wings. A few months later, a historic total of 505 Whooping Cranes was counted on the wintering grounds in Texas. This number is considered to be the halfway point toward a milestone of 1,000 birds in the migratory AransasWood Buffalo population, which may be reached in 20 years at the population's current growth rate. If that number remains stable for the 10 years that follow, the species' status as endangered may be reassessed..$^{50}$

\section{Acknowlegements}

Many people provided photographs and information filed in archives or in other institutional files, for which I am grateful: Donna Bruce, Jordan Ignatiuk, Val Mann, Stan Shadick, Phillip Taylor (Nature Saskatchewan); Mark Dyck, Robert Grocholski (Regina Philatelic Club); James Franks (William Rowan papers, University of Alberta Archives); Kathy Hartley (Vincent Graves Greene Philatelic Foundation); Glenn Sutter, Marlon Janzen (Royal Saskatchewan Museum); Gregory Rand (Canadian
Museum of Nature); and Janet Snell (Nature Vancouver). Mark Brigham and Glenn Sutter offered comments on the manuscript.

1. Allen RP (1952) The Whooping Crane. Research Report of the National Audubon Society, No. 3, New York. 246 pp.

2. COSEWIC (2010) Assessment and status report on the Whooping Crane Grus americana in Canada. Committee on the Status of Endangered Wildlife in Canada, Ottawa, ON. 36 pp.

3. Urbanek PP, Lewis JC (2015) Whooping Crane (Grus americana). Version 2.0. In The Birds of North America (Poole AF, editor). https://doi.org/10.2173/bna.153. 28 pp.

4. Dunlap TR (1991) Organization and wildlife preservation: The case of the Whooping Crane in North America. Social Studies of Science 21:197-221.

5. Johns BW (2019) Whooping Crane. Pages 222-225 in Birds of Saskatchewan (Smith A $R$, Houston C S, and Roy J F, editors). Nature Saskatchewan, Regina. 765 pp. (Records the last nests of the Whooping Crane discovered in Saskatchewan, in the early 1920s.)

6. Robson L (2012) Whooping Crane the 20th century phoenix. The Canadian Philatelist 63:85-90.

7. Hjertaas DG (1994) Summer and breeding records of the Whooping Crane in Saskatchewan. Blue Jay 52:99-115.

8. Novakowski NS (1966) Whooping Crane population dynamics on the nesting grounds, Wood Buffalo National Park, Northwest Territories, Canada. Canadian Wildlife Service Report Series, No. 1, Ottawa, ON. 19 pp.

9. Allen RP (1956) A report on the Whooping Crane's northern breeding grounds. Supplement to Research Report of the National Audubon Society, No. 3, New York. $60 \mathrm{pp}$. (Details the discovery of the nesting grounds, supplemented with correspondence from Canadian Government officials describing the first sightings of Whooping Cranes and the first nesting pair in Wood Buffalo Park in 1954.)

10. Miller RS (1973) The brood size of cranes. Wilson Bulletin 85:436-441.

11. Kuyt E (1995) The nest and eggs of the whooping-crane, Grus americana. Canadian Field-Naturalist 109:1-5.

12. Bergeson DG, Johns BW, Holroyd GL (2001) Mortality of Whooping Crane colts in Wood Buffalo National Park, Canada. Proceedings of the Whooping Crane Workshop 4:6-10.

13. Forbes LS (1990) Insurance offspring and the evolution of avian clutch size. Journal of Theoretical Biology 147:345-359. 
14. Opinions varied on the advisability of egg removal and its effects on Whooping Crane recruitment, but the program helped to develop captive flocks, supported reintroductions, and reduced variance in reproductive success in the Aransas-Wood Buffalo population. There are no current plans to remove eggs again. ${ }^{2}$ As an early supporter of this program, the SNHS found itself in the middle of a controversy, involving the U.S. Fish and Wildlife Service and the National Audubon Society, which was opposed to removing any birds from the wild. ${ }^{24}$ The SNHS's stance, however, was clear. In his March 1957 editorial, George A. Ledingham reiterated the Society's support for "any management program that the International Whooping Crane Advisory Group would propose ... "that healthy cranes could [be raised] from fertile eggs more successfully than cranes would in the wild and he thought that the program should begin with captive birds, and extend to rescuing some of the eggs from which young are not raised in the wild" (Blue Jay 15(1):1, 1957).

15. Pre-and post-issue publicity was widespread: "Whooping Crane stamp gains western support", Calgary Herald, February 15, 1954; "City zoologist's design used for Whooping Crane stamp", Edmonton Journal, December 8, 1954, p. 35 (reprinted in The Canadian Philatelist 6(1):5, 1955; "News of the World of Stamps", New York Times, February 27, 1955, p. 13; "Regina Philatelic Society Whoops it up for Whoopers", The Canadian Philatelist 5(6):19, 1954; "Whooping Crane is on New Stamp", The Canadian Philatelist 5(10):10, 1955.

16. Rowan W (1932) The status of the dowitchers with a description of a new subspecies from Alberta and Manitoba. Auk 49:14-35.

17. Sealy SG (2019) Type specimens of birds collected in the Canadian Prairie Provinces, 1910-1965. Blue Jay 77(4):20-27.

18. Ainley MG (1993) Restless Energy: A Biography of William Rowan 1891-1957. Véhicule Press, Montréal, QC. 368 pp.

19. William Rowan to P.A. Taverner, October 26, 1939, cited in reference \#4 (p. 201). (The letter was not located in the files of the Canadian Museum of Nature.)

20. Walkinshaw LH (1965) A new Sandhill Crane from central Canada. Canadian FieldNaturalist 79:181-184.

21. Rowan W (1926) On photoperiodism, reproductive periodicity and the annual migrations of birds and certain fishes. Proceedings of the Boston Society of Natural History 38:147-189.
22. Rowan W (1930) Experiments in bird migration. II. Reversed migration.

Proceedings of the National Academy of Sciences 16:520-525.

23. Rowan W (1931) The Riddle of Bird Migration. Williams \& Wilkins Co., Baltimore, MD. 151 pp.

24. Belcher M (1996) The legacy of Isabel Priestly: Saskatchewan Natural History Society 1949-1990. Saskatchewan Natural History Society, Special Publication, No. 19. 286 pp. (High-lighted were efforts to publicize the plight of the Whooping Crane in Saskatchewan and beyond, initiated from the outset by Isabel Priestly, and to provide support for conservation initiatives, frequently through resolutions at annual meetings of the SNHS. For example, the Society worked with the Whooping Crane Conservation Association, among other groups, and declared 1954, the year that preceded the issue of the stamp, as the "Whooping Crane Year", and adopted the motto "Protect the Whooper." ${ }^{25}$ )

25. Stueck RP (1953) A message from the President. Blue Jay 11(4):1.

26. Post Office Department. Invitation for postage stamp designs. (University of Alberta Archives [UAA] William Rowan [WR] papers, box 48, folder 1085).

27. L.J. Mills, Director of Financial Services, Post Office Department, Ottawa, to Rowan, June 28, 1951 (UAA, WR papers, box 48, folder 1085, Part 3).

28. Rowan to the Right Honourable Vincent Massey, September 23, 1951 (UAA WR papers, box 48 , folder 1086).

29. Rowan to the Right Honourable Vincent Massey, January 31, 1953 (UAA WR papers, box 48, folder 1086).

30. Rowan's letters soliciting support for the proposed stamp, including announcements and correspondence pertaining to the joint proposal, are archived at the University of Alberta (UAA WR papers, box 48, folder 1088).

31. Anonymous (1954) Regina Philatelic Society whoops it up for whoopers. The Canadian Philatelist 5(6):10.

32. Bard FG (1958) Whooping Cranes, 1958. Blue Jay 16:11-14

33. Apperley R, Lahrman FW (1990) In memorium - Dr. Frederick George Bard. Blue Jay 48:168-170.

34. Fred W. Bard to Rowan, January 26, 1954 (UAA WR papers, box 48, folder 1086).

35. Scott L (2003) Fred W. Lahrman, 1921-2003. Blue Jay 61:186-188.

36. Lahrman FW (1972) The Whooping

Crane in Saskatchewan. Blue Jay 30:146-150.
37. Photograph of the diorama in Blue Jay 13(2):16-71, 1955. (Everything but the mounted birds were destroyed in a fire in 1990 [G.C. Sutter, email, March 11, 2019.])

38. It was premature for Rowan to describe this region as part of the Whooping Crane's migratory route, because the nesting ground and the route used to reach it had not been confirmed when the proposal was submitted. The photograph was taken about one year before the nesting ground was discovered.

39. Rowan to F.G. Bard, March 29, 1955 (UAA WR papers, box 48, folder 1088).

40. Rowan to D. Adamson, March 30, 1955 (UAA WR papers, box 48, folder 1088).

41. D. Adamson to Rowan, April 5, 1955 (UAA WR papers, box 48, folder 1088).

42. F.G. Bard to Rowan, April 6, 1955 (UAA WR papers, box 48, folder 1088).

43. Rowan to F.G. Bard, May 4, 1955 (UAA WR papers, box 48, folder 1088).

44. Of nine first-day covers of this issue I examined on the Internet, plus one shown in reference \#6 (p. 88), nine were postmarked at Ottawa, and one at Ingersoll, Ontario; none was cancelled with this slogan.

45. L.W. Bentham to Rowan, February 12, 1957; Rowan to Bentham, February 21, 1957 (UAA WR papers, box 48, folder 1088).

46. Bentham LW (1957) Dr. Rowan and designed Canada's Whooping Crane $5 \not \subset$ of 1955. Scott's Monthly Journal 38(3):48-49.

47. Anonymous (1956) Whooping Crane Model for Stamp, Edmonton Journal, September 11.

48. Rowan to Editor, Edmonton Journal, September 20, 1956. (Peter Scott was an ornithologist and artist with the renowned Severn Wildfowl Trust at Slimbridge, England.)

49. Robert A. McCabe to Rowan, December 29, 1953 (UAA WR papers, box 48, folder 1086).

50. Devokalitis, M (2019) Whooping Crane population hits historic high in 2018. https://www.allaboutbirds.org/whoopingcrane-population-hits-historic-high-in-2018 (accessed February 23, 2019). 